\title{
THE INFLUENCE OF STORE ENVIRONMENT, SALES PROMOTION AND PERCEIVED VALUE ON PURCHASE DECISION
}

\author{
CHAPHIRAY \\ IRMA SATYA INDRIYANTI \\ Trisakti School of Management, Jl. Kyai Tapa No. 20, Grogol, Jakarta, Indonesia \\ piraylaw@gmail.com, isy@stietrisakti.ac.id
}

\begin{abstract}
The purpose of this research is to test and analyze influence of Store Environment, Sales Promotion, and Perceived Value to Purchase Decision to Customer Ramayana in East Jakarta. The research design used in descriptive research and causality research. The sampling in the study used 206 respondent with purposive sampling. The research data is processed with IBM Statistic 22.0 as a tool. This study uses multiple regression analysis. The result showed that Store Environment, Perceived Value influence Purchase Decision, but for Sales Promotion not influence to Purchase Decision. Overall, independent variables affect Loyalty simultaneously.
\end{abstract}

Keywords: Store environment, sales promotion, perceived value, purchase decision

\begin{abstract}
Abstrak: Tujuan penelitian adalah untuk menguji dan menganalisa pengaruh. Store Environment, Sales Promotion, Perceived Value terhadap Purchase Decision konsumen Ramayana di Jakarta Timur. Penelitian ini menggunakan rancangan penelitian kausalitas dan deskriptif. Sampling dalam penelitian ini adalah Purposive Sampling dan diperoleh sampel sebanyak 206 responden. Penelitian ini menggunakan metode statistik dengan program IBM statistic 22.0 sebagai alat ujinya. Penelitian ini menggunakan analisis regresi berganda. Hasil penelitian menunjukan bahwa Store Environment, Perceived Value berpengaruh terhadap Purchase Decision. Tetapi untuk Sales Promotion tidak berpengaruh terhadap Purchase Decision. Secara keseluruhan variabel independen mempengaruhi Purchase Decision secara bersama-sama.
\end{abstract}

Kata Kunci: Store environment, sales promotion, perceived value, purchase decision

\section{INTRODUCTION}

Gross Domestic Product (GDP) is an indicator to measure a country's economic conditions within a specified time, the market value of goods and services produced by a country in a certain time and is the production of goods and services produced by economic units. In Indonesia, the retail business is differentiated. into 2 groups, namely traditional retail and modern retail. Traditional markets are markets that are built and managed by the
Government, in the form of tents, shops, booths and kiosks managed by small, medium and non-governmental traders or as cooperatives, small capital and by the process of buying and selling goods through a bargaining process. and Modern Markets, namely shops with independent service systems, selling various types of products in retail in the form of minimarkets, supermarkets, hypermarkets, department stores and others..

Department Store is a type of business in the form of retail that provides a wide variety of products as 
well as products including household appliances, clothing and other necessities. Purchases, services and promotions are usually carried out in each section to make it easier for consumers to shop and are usually led by someone who is responsible for the overall form and also the personnel.

Therefore, the study wanted to test whether the Store Environment, Sales Promotion, Perceived Value variables in the Ramayana company would affect Purchase Decision or not.

\section{Store Environment}

Schiffman dan Wisenblit (2019:135) mendifinisikan store atmosphere adalah "must matchs the expectations of the shoppers in order to avoid perceived over or understimulation"

Kotter and Keller (2016:561) store atmosphere adalah "every store has a looks and a physical loyout that makes it hard or easy to move around for helping store to sell"

Keegan and Green (2015:400) store atmosphere adalah " a company may possess competencies that can be the basis for competitive advantage in a particular retail market".

Hanaysha (2018) store environment adalah "in the retail context found that the ambience and store's design are important features that affect brand preference, service and product quality and price perceptions"

Wisman (2015) Defining a store environment is a good store environment that can attract buyers, make customers comfortable in shopping and remind the products that need to be owned for both personal and household needs.

Based on the above definition, a store environment is an atmospheric environment that is formed in terms of layout, color layout, store design, decoration, music, space, aesthetics and an environment that is considered important so that consumers are interested and shop at the store.

\section{Sales Promotion}

Lovelock and Wirt (2016:257) sales promotion adalah "as a communication with an incentive sales promotion usually are specific to a time period, price, or customer group"
Kotter and Keller (2016:622) sales promotion adalah " a key ingredient in marketing campaigns, consists of collection of incentive tool, mostly short terms, designed to stimulate quicker or greater purchase of particular products or service by cosumers or the trade"

Keegan and Green (2015:449) sales promotion adalah " refres to any paid consumers or trade communication program of limited duration that adds tangible value to a product or brand"

Hanaysha (2018) mendifinisikan sales promotion adalah "as an important component in marketing campaigns for isnpining and simulating quicker and effective response (comporising purchase quantity and speed) to the sales of particular products or service"

Pelawi (2015) defining sales promotion is a sales promotion is one part of a new promotion that offers added value to consumers by motivating consumers to see the product and then be interested in making a purchase of the product offered.

Based on the above understanding, sales promotion is concluded as a marketing strategy used to attract customers and attract consumers to make purchases on product sales by providing special offer prices.

\section{Perceived Value}

Schiffman dan Wisenblit(2019:126) perceived value adalah "How a consumer perceives a price as low, high, or fair strong influences both purchase intentions and post purchase satisfaction"

Lovelock and Wirt (2016:73) perceived value adalah "that the customer can choose between two or more standardized options, but without changing their option"

Kotter dan Keller (2016:151) perceived value adalah "Perceived valueis the difference between the prospective customer's evaluation of all the benefits and all the cost of an offering and the perceived"

Lonita dan Ruslim (2019) perceived value is the overall assessment made by consumers of the usefulness of a product based on what is received and what is given. 
Based on the above understanding, perceived value can be interpreted as a consumer's overall assessment of the benefits of a product based on what is received and what is given.

\section{Purchase Decision}

Lovelock dan Wirtz (2016:64) purchase decision adalah "purchase decision is situation when consumer ready to select the options they like best, after consumer have evaluated possible altemative".

Kotter dan Keller (2016:198) purchase decision adalah "in the evaluation stage, the consumer forms preference among the brand in the choice setand may also form an intention to buy most preffered brand"

Briliana (2015) Purchase decision is a decision taken by a person to choose a product that suits his needs and desires after considering various altematives including the price offered and the benefits obtained.

Based on the above understanding, the purchase decision is a consumer behavior that shapes and evaluates to choose between several established brands and creates an intention so as to decide to buy from a brand

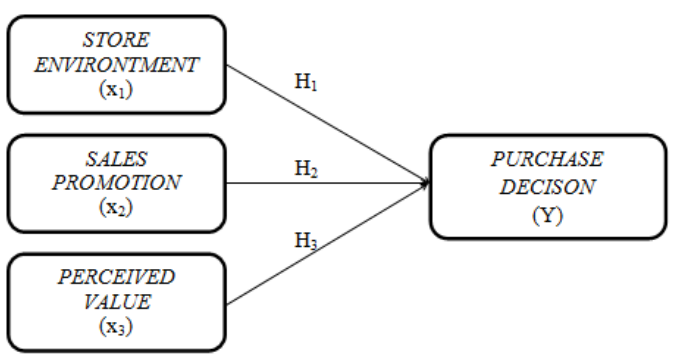

Picture 1 Research model

\section{RESEARCH METHOD}

In this study the design used was descriptive and causality research. Which aims to determine the effect of the store environment, sales promotion, perceived value on the purchase decision of Ramayana consumers in East Jakarta.

The object of the research is Ramayana consumer visitors in East Jakarta. And data collection using a questionnaire as a primary data collection tool. Respondents of this study were shopping at Ramayana in East Jakarta twice in the last 2 months.

The number of samples that were planned to be taken by the researcher was 210 respondents, where the sample had exceeded the number of large samples determined by Hair et al. (2014:100) at least 100 respondents.

This study uses multiple regression analysis, according to Hair et al. (2014:154) multiple regression analysis is "multiple regression is a regression model with two or more independent variables" All data collected were processed using SPSS 22.0 
Table 1 Variables and Measurement Scale

\begin{tabular}{llll}
\hline No & Variabel & Question indicator & Skala \\
\hline 1 & Store Environment (X1) & 1. & Ramayana shop is always clean \\
& 2. & Ramayana shop has a nice atmosphere \\
& with music \\
3. & The ambiance and decorations at the \\
& Ramayana shop encourage me to visit \\
& again \\
4. & The quality of the cooling machine (AC) \\
& at the Ramayana shop makes my \\
& presence in it feel comfortable
\end{tabular}

\begin{tabular}{ll}
\hline 2 Sales Promotion (X2) & 1. $\begin{array}{l}\text { Ramayana shop price quotes are Likert } \\
\text { frequently offered }\end{array}$ \\
2. & Seasonal promotions are available at \\
& Ramayana stores \\
3. Attractive Ramayana shop price offers
\end{tabular}

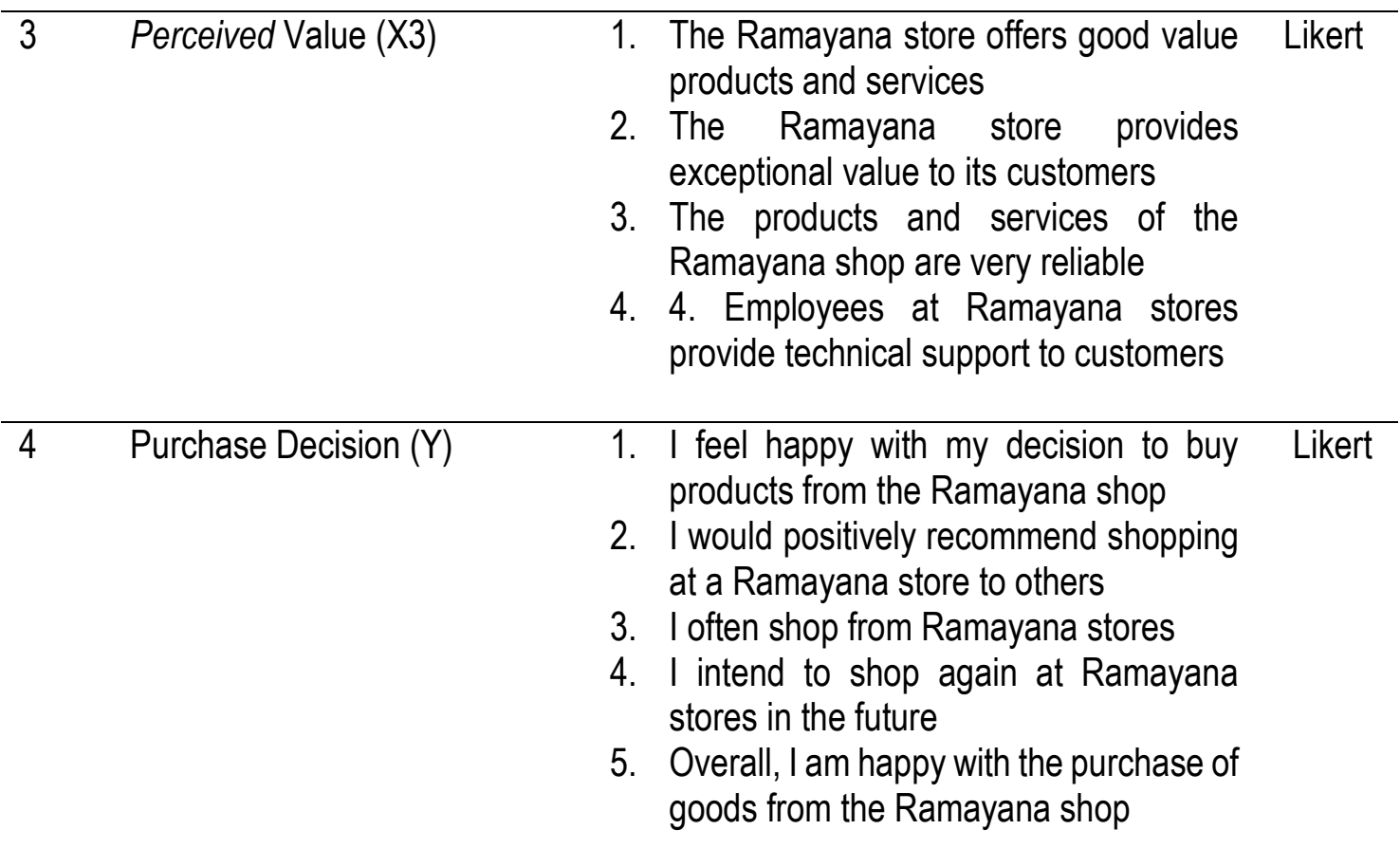




\section{RESUT AND DISCUSSION}

Table 1 Adjusted R-square

\begin{tabular}{lcccc}
\hline Model & $R$ & R Square & $\begin{array}{c}\text { Adjusted R } \\
\text { Square }\end{array}$ & $\begin{array}{c}\text { Std. Error of the } \\
\text { Estimate }\end{array}$ \\
\hline 1 & $.608^{\mathrm{a}}$ & .370 & .361 & 1.502 \\
\hline Sumber : pengolahan data SPSS 22.0 Jumi 2020 & &
\end{tabular}

In table 1 it can be seen that the Adjusted $\mathrm{R}$ Square value is 0.361 which means that $36.1 \%$ of the variation in the Purchase Decision $(\mathrm{Y})$ variable can be explained by variations in the Store Environment (X1), Sales Promotion (X2) and Perceived Value (X3) variables while the rest is $63.9 \%$ is explained by variations in other variables that are not present in this study

Tabel 2 Hasil Uji F

\begin{tabular}{|c|c|c|c|c|c|c|}
\hline \multirow[b]{2}{*}{ Model } & & Sum of & \multicolumn{3}{|c|}{ Mean } & \multirow{3}{*}{$\frac{\text { Sig. }}{.000^{\mathrm{s}}}$} \\
\hline & & Squares & Df & Square & $\mathrm{F}$ & \\
\hline \multirow[t]{3}{*}{1} & Regression & 267.335 & 3 & 89.112 & 39.524 & \\
\hline & Residual & 455.427 & 202 & 2.255 & & \\
\hline & Total & 722.762 & 205 & & & \\
\hline
\end{tabular}

There are two F Test approaches to determine a model is said to be fit

1. P-Value Approach

In table 2 it can be seen that the sig value is 0,000 where the a value is 0.05 . The $p$-value $(0,000)<a(0.05)$, then it can be concluded that the model is fit criteria.

2. Critical Value Approach

In table 2 it can be seen that the Fcount value is 39,524 while the $F a$ value is 2.70 , the $\mathrm{Fa}$ value is obtained by considering the value of df1 $=3$ and df2 $=202$ or with the formula df $2=206-3-1$ $=202$ and the value $a=0.05$.

The value of Fcount $(39,524)>$ Ftable (2.70), then it can be concluded that the model is fit criteria.
Table 3 Test results T

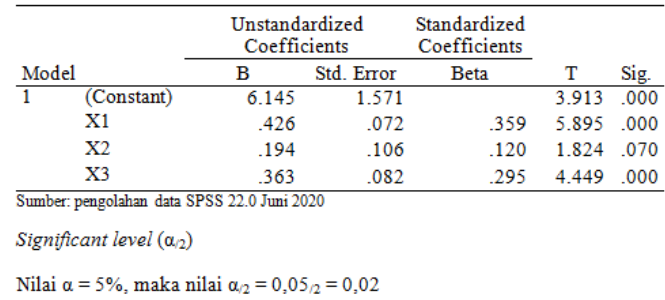

Value - t-count $\leq$ - t-table $(5,895 \geq 1,960)$ so it can be concluded that $\mathrm{Ha}$ is accepted, meaning that there is an effect of Store Environment on Purchase Decision of Ramayana consumers in East Jakarta.

The value of $t$-count $>$ t-table $(1,824$ $<1,960$ ), so it can be concluded that $\mathrm{Ha}$ is rejected, meaning that there is no effect of Sales Promotion on Purchase Decision of Ramayana consumers in East Jakarta.

The value of t-count> t-table (4.449> $1.960)$, so it can be concluded that $\mathrm{Ha}$ is accepted, meaning that there is an effect of Perceived Value on Purchase Decision of Ramayana consumers in East Jakarta.

\section{CLOSING}

Based on the results of the analysis and discussion carried out in chapter IV, the following conclusions are obtained:

1. There is an influence of Store Environment on Purchase Decision of Ramayana consumers in East Jakarta.

2. There is no effect of Sales Promotion on Purchase Decision of Ramayana consumers in East Jakarta.

3. There is an influence of Perceived Value on Purchase Decision of Ramayana consumers in East Jakarta. 


\section{REFERENCES:}

Briliana, 2015, Pengaruh Retail Mix terhadap Purchase Decision pada pelanggan Lotte Mart di Cabang

Fatmawati Jakarta Selatan. Jurnal bisnis dan akutansi, 17(2), 1-12

decision in the Malaysian retail market", Emerald Publishing Limited, pp.7-23.

Ghozali, Imam. 2018. Aplikasi Analisis Multivariete dengan program IBM SPSS 25. Semarang: Badan Penerbit Universitas Diponegoro.

Hair, Joseph F., et al. 2014. Multivariate Data Analysis. England: Pearson Education Limited.

Hanaysha, 2018, "An examination of the factors affecting consumer's purchase

Keegan dan Green. 2015. Global Marketing 8th Edition. Global Edition: Pearson.

Kotler, Philip, dan Kevin Lane Keller. 2016. Marketing Management $15^{\text {th }}$ Edition. England: Pearson Education Limited

Lonita, 2019, Sales Promotion, Store Environment Dan Perceived Value Sebagai Prediktor Terhadap Purchase Decision. Jurnal Majerial dan kewirausahaan, 1(3), 1-8.

Lovelock, Christopher, dan Jochen Wirtz. 2016. Service Marketing: People, Technology, Strategy $8^{\text {th }}$ Edition. England: People Technology Strategy

Neolaka, Amos. 2014. Metode Penelitian dan Statistik Cetakan Pertama: untuk

Perkuliahan Mahasiswa Sarjana dan Pasca Sarjana. Bandung: PT Remaja Rosdakarya.

Schiffman, Leon G, and Joseph L. Wisenblit. 2019. Consumer Behaviour, $12^{\text {th }}$ Edition. Global Edition: Pearson

Sekaran, Uma dan Roger Bougie. 2016. Research Methods for Business. United Kingdom: John Wiley \& Sons Ltd.

Sugiyono. 2018. Metode Penelitian Kuantitatif, Kualitatif, dan R\&amp;D. Bandung: Alfabeta.

Wisman, I, 2015, Pengaruh lingkungan toko (Store Environment) terhadap keputusan pembelian konsumen pada minimarket srinadi di Semerapura tahun 2014. 5(1), 1-10. 